\title{
Relation Between Resistance to Leaf Rust and Fusarium Crown Rot Diseases in Some Egyptian Wheat Cultivars
}

\author{
Mohamed E. Selim ${ }^{1}$, Abeer H. Makhlouf ${ }^{1}$, Gamal A. Ahmed ${ }^{2}$
}

\begin{abstract}
Wheat (Triticum aestivum $\mathrm{L}$ ) is the most important cereal crop worldwide. It is responsible for providing more than $40 \%$ of humans with their nutritional requirements from carbohydrates and other essential nutrients. Unfortunately, its attacked by different various air and soil borne pathogens which resulted in massive losses in both yield quantity and quality. In Egypt, wheat is not only just a nutritional cereal crop, but it is considered the food security key. There is a huge gap between the wheat grain production and national consumption levels. Therefore, saving each grain from wheat production deemed urgent need. Using resistant cultivars against important invaded pathogens is considering one of the most effective and relevant techniques that can be used in the battle between plant pathologists and hazardous pathogen i.e. Puccinia triticina and Fusarium pseudograminiarum. In the current study, the resistance potential of 29 different Egyptian wheat cultivars was assessed against 3 leaf rust races and crown rot disease individually. The results showed that the tolerance potential of the tested cultivars toward either $\boldsymbol{P}$. triticina or $F$. pseudograminiarum was varied significantly. Also, the relation between the incidences of the two diseases was estimated. Results indicating that there are a positive correlation between incidence of leaf rust and incidence of crown rot diseases. These findings could lead to designing special models which can be used in the prediction of the incidence by one of the two pathogens when the other attacks the wheat plants.
\end{abstract}

Key words:wheat- Fusarium- leaf rust- crown rot.

\section{INTRODUCTION}

Leaf rust due to Puccinia triticina Eriks., is important and widespread diseases of common wheat (Triticum aestivum L.) worldwide. It is adapted to a wide range of environments, occurs wherever wheat is grown and can cause significant yield losses (Wamishe and Milus, 2004). The losses due to leaf rust reach more than $50 \%$ under favorable field conditions on the susceptible wheat cultivars (German et al., 2007). In Egypt, there are losses in grain yield due to the artificial leaf rust which reached to $32 \%$ in the susceptible wheat cultivars that cultivated under experimental field conditions suitable to disease incidence and development (Shahin and El-Orabey 2016; El-Orabey et al., 2017). Utilizing the resistant wheat cultivars is one of the most economic and effective methods to control leaf rust of wheat (Elyasi-Gomari and Lesovaya, 2009 and El-Orabey et al. 2019).

Fusarium crown rot (FCR) on wheat caused by $F$. pseudograminearum and $F$. graminearum and concerning one of most critical and devastating soilborne diseases on wheat global. This disease can have a highly negative impact on wheat production which leads to a significant reduction in grain yield (Bai and Shaner, 2004) especially under favorable conditions i.e., wet, humid weather during anthesis and early grain fill. Yield losses due to FCR results from reduction in the number of kernels and shriveled kernels. The pathogen causes necrosis lesion on the stem base as well as on the crown. The fungus produces also mycotoxins during infection, in particular deoxynivalenol (DON), this reduces the grain quality due to the accumulation of DON mycotoxin, which causes a significant risk to human and animal health after consumption (McMullen et al., 1997 and Ferrigo et al., 2016). Thus, crown rot of wheat is an important plant disease that needs to be well managed due to its detrimental effects that it can have on entire fields of wheat.

The epidemic of $F$. pseudograminearum can develop during stressful water deficits in fields and can spread quickly to other wheat plants, whose symptoms will ultimately lead to plant death (Mudge et al., 2006)

Newly, this crucial disease has spread to others wheat-growing areas worldwide and has been considered a major threat to wheat production in many countries since the early $20^{\text {th }}$ century (Goswami \& Kistler, 2004). The economic losses in wheat and barley caused by $F$. pseudograminearum and $F$. graminearum were estimated at about $\$ 7.67$ billion from 1993 to 2001 for nine states in the northern Great Plains and the central USA (Illinois, Indiana, Kentucky, Michigan, Missouri, Minnesota, Ohio, South Dakota, and North Dakota) (Nganje et al., 2004). In Kansas only, losses were valued at $\$ 57$ million in 2008 alone (McMullen et al., 2012). Fusarium head blight and Fusarium crown rot epidemics have been reported in most of the wheat production areas worldwide (Dubin et al., 1997;

DOI: 10.21608/asejaiqjsae.2021.176091

${ }^{1}$ Agricultural botany Dept., Fac. Of Agric., Menoufiya University. Egypt.

${ }^{2}$ Plant Pathol. Dept., Fac. Agric., Moshtohor, Benha University. Egypt.

Corresponding Author: G. A. Ahmed, Benha University,

Faculty of Agriculture - Moshtohor, Toukh, Kalyoubia, 13736, Egypt

E-mail: gamal.mohamed@fagr.bu.edu.eg

Received April 30, 2021, Accepted, June 07, 2021. 
McMullen et al., 2012). The main objectives of the current study were to evaluate the resistance potential of some Egyptian wheat cultivars against leaf rust and Fusarium crown rot to detect the promising resistance cultivars against both pathogens to find the possible correlation between leaf rust and FCR genetic inheritance.

\section{MATERIAL AND METHODS}

\section{Evaluation wheat cultivars to leaf rust at seedling stage:}

Evaluation of the tested wheat cultivars to leaf rust was carried out at the seedling stage in the greenhouse of Faculty of agriculture, Shibin El-Kom, Minufiya University, Egypt during 2018/2019 growing season.

\section{Plant materials and $\boldsymbol{P}$. triticina pathotypes}

Seeds of 23 wheat cultivars that were used in the current study included 17 Egyptian wheat cultivars and 5 leaf rust resistance genes as listed in Table 1. Five wheat leaf rust resistant cultivars were sown separately in $6 \mathrm{~cm}$ square plastic pots. Five seeds of each wheat cultivar were sown singly in each corner in clockwise order. Seven days old seedlings of the tested wheat cultivarscultivars, when the first leaf full emerged, were inoculated with urediniospores of 3 collected pathotypes. The spores of each 3 identified pathotypes kindly provided by Dr. Walid Mohamed El-Orabey, Wheat Diseases Res. Dept., Plant Pathology Res. Inst., ARC, Giza, Egypt. These pathotypes were i.e., NTTJT, PTTTT and TTTBT which were the most frequent during 2017/18 growing season (El-Orabey et al., 2018 and El-Orabey et al., 2019). Moreover, these pathotypes were collected and vacuumed during 2017/18 growing season and stored in the refrigerator until use during 2018/2019 growing season. Inoculation was carried out according to Stakman et al. (1962). Wheat seedling leaves ( 7 days old) were rubbed gently between misted fingers with tap water, and then sprayed with water then inoculated by shaking with each of the tested three races over the plant leaves. The inoculated plants were sprayed gently again with water to form an initial film of free water on the plants which is essential for spore germination and establishment of infection. The inoculated plants were incubated in humid chambers for 24 hours to allow spore germination and cause infection. The inoculated plants were moved onto the benches in the greenhouse where daily temperature varied between $18-20^{\circ} \mathrm{C}$ and $100 \% \mathrm{RH}$.

\section{Leaf rust assessment:}

Infection types (IT) data for each of the tested wheat cultivars were recorded after 12 days of inoculation using standard infection type scoring scale 0-4 according to (Stakman et al., (1962). Wheat cultivars that showed low infection types (scores $=0,1$, and 2 ) were considered as resistant or low infection types (LITs). While those with scores $=3$ and 4 were susceptible or high infection types (HITs) (Stakman $e t$ al., (1962).

\section{Crown Rot mass production:}

A monosporic local isolate of Fusarium species ( $F$. graminearum and $F$. pseudograminearum) were transferred on a synthetic nutrient agar and cultured at a temperature of $23^{\circ} \mathrm{C} \pm 1{ }^{\circ} \mathrm{C}$ with a $12 \mathrm{~h}$ photoperiod for 10 days for spore formation. Oven bags $(35 \mathrm{~cm} \times 48$ $\mathrm{cm}$ ), quarter filled with wheat bran, are humidified and sealed with cotton. The bags are autoclaved at $121^{\circ} \mathrm{C}$ for 20 min over three successive days. Spore suspension is prepared by adding sterilized distilled water to each petri dish containing Fusarium culture. Bags of the autoclaved wheat bran were left to cool down and then inoculated with the spore suspension under sterilized conditions. Inoculated wheat bran is mixed by shaking the bags and incubated at a temperature of $23^{\circ} \mathrm{C} \pm 1{ }^{\circ} \mathrm{C}$ for 2-3 weeks with a $12 \mathrm{~h}$ photoperiod until the bran is sufficiently colonized by the fungus. Finally, funguscolonized wheat bran is left to dry at room temperature. The Fusarium species inoculum was saved for use in further studies.

\section{Disease assessment:}

At harvest the tillers of each replicate were sampled, and crown scores are given for each tiller based on browning on the crown/stem base. Crown and roots of plants were scored according to the following scale: 1: 1-9\% (R), 2: 10-29\% (MR) 3: 30-69\% (MS) 4: 70-89\% (S) 5: 90-99\% (HS) (Wallwork et al., 2004).

Sodium dodecyl sulfate-polyacrylamide gel electrophoresis (SDS-PAGE):

Eighty microliters of protein from leaves sample were subjected to SDS-polyacrylamide gel electrophoresis which performed in $12 \%$ acrylamide slab gels following the system of Laemmli (1970) to identify their protein profiles. Gels were photographed scanned, analyzed using Gel Doc VILBER LOURMAT system.

\section{Statistical analysis:}

Data were statistically analyzed according to standard analysis of variance by a one-way ANOVA with Stat graphics (Statistical Graphics, Rockville, MD, USA) software; Variance homogeneity for all treatments was confirmed by the Bartlett test. Tukey's test was used to compare differences between different treatments if the F value was significant. Statistical differences referred to in the text were significant at $(\mathrm{P}<0.05)$ as given in the Figures. 
Table 1. List of the tested wheat cultivars used in this study, pedigree, and year of release

\begin{tabular}{|c|c|c|}
\hline Genotype & Pedigree & $\begin{array}{l}\text { Year of } \\
\text { release }\end{array}$ \\
\hline Sids 1 & HD2172/PAVON"S"//1158.574"S". SD46-4SD-2SD-1SD-0SD. & 1996 \\
\hline Sids 12 & $\begin{array}{l}\text { BUC//7C/ALD/5/MAYA74/ON//1160- } \\
\text { 147/3/BB/GLL/4/CHAT"S"/6/MAYA/VUL-4SD-1SD-1SD-0SD. }\end{array}$ & 2007 \\
\hline Sids 13 & $\begin{array}{l}\text { KAUZ "S"//TSI/SNB"S". ICW94-0375-4AP-2AP-030AP-0APS-3AP-0APS- } \\
\text { 050AP-0AP-0SD. }\end{array}$ & 2010 \\
\hline Sids 14 & SW8488*2/ KUKUNACGSS01Y00081T-099M-099Y-099M-099B-9Y-0B-0SD. & 2018 \\
\hline Gemmeiza 7 & CMH74A.630/SX//SER182/3/AGENT. GM4611-2GM-3GM-1GM-0GM. & 1999 \\
\hline Gemmeiza 9 & ALD"S"/HUAC"S"//CMH74A.630/SX. GM4583-5GM-1GM-0GM. & 1999 \\
\hline Gemmeiza 11 & $\begin{array}{l}\text { B0W"S"/KVZ"S"//7C/SERI82/3/GIZA168/SAKHA61. GM7892-2GM-1GM- } \\
\text { 2GM-1GM-0GM. }\end{array}$ & 2011 \\
\hline Gemmeiza 12 & $\begin{array}{l}\text { OTUS/3/SARA/THB//VEE .CCMSS97Y00227S-5Y-010M-010Y-010M-2Y- } \\
\text { 1M-0Y-0GM }\end{array}$ & 2017 \\
\hline Sakha 93 & Sakha 92/TR 810328 S 8871-1S-2S-1S-0S & 1999 \\
\hline Sakha 94 & $\begin{array}{l}\text { OPATA/RAYON//KAUZ. CMBW90Y3280-0TOPM-3Y-010M-010M-010Y- } \\
\text { 10M-015Y-0Y-0AP-0S. }\end{array}$ & 2004 \\
\hline Misr 1 & $\begin{array}{l}\text { OASIS/SKAUZ//4*BCN/3/2*PASTOR. CMSSOYO1881T-050M-030Y-O3OM- } \\
\text { 030WGY-33M-0Y-0S. }\end{array}$ & 2010 \\
\hline Misr 2 & SKAUZ/BAV92. CMSS96M0361S-1M-010SY-010M-010SY-8M-0Y-0S. & 2011 \\
\hline Misr 3 & $\begin{array}{l}\text { ATTILA*2/ABW65*2/KACHU CMSS06Y00258 2T-099TOPM-099Y- } \\
\text { 099ZTM-099Y-099M-10WGY-0B-0EGY }\end{array}$ & 2018 \\
\hline Giza 168 & MIL/BUC//Seri CM93046-8M-0Y-0M-2Y-0B & 1999 \\
\hline Giza 171 & Sakha 93 / Gemmeiza 9 S.6-1GZ-4GZ-1GZ-2GZ-0S & 2013 \\
\hline Shandweel 1 & $\begin{array}{l}\text { SITE//MO/4/NAC/TH.AC//3*PVN/3/MIRLO/BUC. CMSS93B00567S-72Y- } \\
\text { 010M-010Y-010M-0HTY-0SH }\end{array}$ & 2011 \\
\hline Sakha 95 & $\begin{array}{l}\text { PASTOR//SITE/MO/3/CHEN/AEGILOPS SQUARROSA(TAUS)//BCN } \\
\text { /4/WBLL1CMSA01Y00158S-040P0Y-040M-030ZTM-040SY-26M-0Y-0SY-0S }\end{array}$ & 2018 \\
\hline $\operatorname{Lr} 9$ & Thatcher ${ }^{6} \mathrm{x}$ Tranfer & - \\
\hline $\operatorname{Lr} 10$ & Thatcher ${ }^{6} \mathrm{x}$ Exchange & - \\
\hline $\operatorname{Lr} 19$ & Thatcher ${ }^{6} \mathrm{x}$ A. elongatum & - \\
\hline $\operatorname{Lr} 24$ & Thatcher ${ }^{6} \mathrm{x}$ Agent & - \\
\hline $\operatorname{Lr} 34$ & Thatcher $^{6}$ x P.I. 58548 & - \\
\hline $\operatorname{Sr} 2$ & Triticum aestivum $\mathrm{X}$ Triticum turgidum & - \\
\hline \multicolumn{2}{|c|}{249 (Check CR-MR) } & - \\
\hline \multicolumn{2}{|c|}{ Altay (Check CR-MR) } & - \\
\hline \multicolumn{2}{|c|}{ Carisma (Check CR-MR) } & - \\
\hline \multicolumn{2}{|c|}{ Kutluk (Check CR-S) } & - \\
\hline \multicolumn{2}{|c|}{ Seri (Check CR-S) } & - \\
\hline \multicolumn{2}{|c|}{ Sunco(Check CR-MR) } & - \\
\hline
\end{tabular}

\section{RESULTS AND DISCUSSION}

\section{Results}

Evaluation of wheat cultivars against leaf rust during the seedling stage under greenhouse conditions:

Reactions of 23 wheat cultivars against the most frequent leaf rust pathotypes i.e. NTTJT, PTTTT and TTTBT during the two growing seasons. 2018/2019 and
2019/2020 were recorded as shown in Tables $2 \& 3$ and Figs. $1,2 \& 3$. The results of the two growing seasons showed that nine wheat cultivars; Sids 13, Gemmeiza 9, Sakha 95, Misr 1, Misr 3, Giza 17, Lr 10, Lr 19 and Sr 2 comp. recorded the lowest infection type against pathotype NTTJT, while the other 14 tested wheat cultivars recorded the high infection type against the same pathotype (Fig. 1). Moreover, 8 cultivars; Sids 13, Gemmeiza 9, Sakha 95, Misr 1, Misr 3, Giza 17, Lr 19 
and $\operatorname{Sr} 2$ comp. showed the lowest infection type against pathotype PTTTT. The other 15 tested wheat cultivars showed high infection type against pathotype PTTTT (Fig. 2). While the 6 wheat cultivars; Gemmeiza 9,
Sakha 95, Misr 1, Misr 3, $\operatorname{Lr} 10$ and $\operatorname{Sr} 2$ comp. showed low infection type against pathotype TTTBT. The other 17 tested wheat cultivars showed high infection type against pathotype TTTBT (Fig. 3).

Table2. Infection types of 23 wheat cultivars against the most frequent leaf rust pathotypes at seedling stage under greenhouse condition during 2018/2019 growing season

\begin{tabular}{|c|c|c|c|c|}
\hline \multirow{2}{*}{ No. } & \multirow{2}{*}{ Genotype } & \multicolumn{3}{|c|}{ Leaf rust pathotypes / Infection type* } \\
\hline & & NTTJT & PTTTT & TTTBT \\
\hline 1 & Sids 1 & 3 & 4 & 4 \\
\hline 2 & Sids 12 & 4 & 3 & 3 \\
\hline 3 & Sids 13 & 2 & 2 & 3 \\
\hline 4 & Sids 14 & 4 & 3 & 3 \\
\hline 5 & Gemmeiza 7 & 3 & 4 & 3 \\
\hline 6 & Gemmeiza 9 & 1 & 0 & 0 \\
\hline 7 & Gemmeiza 11 & 4 & 4 & 4 \\
\hline 8 & Gemmeiza 12 & 3 & 3 & 4 \\
\hline 9 & Sakha 93 & 3 & 4 & 3 \\
\hline 10 & Sakha 94 & 3 & 4 & 3 \\
\hline 11 & Sakha 95 & 0 & 0 & 0 \\
\hline 12 & Misr 1 & 2 & 1 & 2 \\
\hline 13 & Misr 2 & 3 & 3 & 4 \\
\hline 14 & Misr 3 & 0 & 0 & 0 \\
\hline 15 & Giza 168 & 3 & 3 & 4 \\
\hline 16 & Giza 171 & 2 & 2 & 3 \\
\hline 17 & Shandweel 1 & 4 & 3 & 4 \\
\hline 18 & $\operatorname{Lr} 9$ & 3 & 3 & 4 \\
\hline 19 & $\operatorname{Lr} 10$ & 2 & 3 & 2 \\
\hline 20 & $\operatorname{Lr} 19$ & 2 & 2 & 3 \\
\hline 21 & $\operatorname{Lr} 24$ & 3 & 4 & 3 \\
\hline 22 & Lr 34 & 4 & 3 & 4 \\
\hline 23 & Sr 2 comp. & 2 & 0 & 1 \\
\hline 24 & Morocco & 4 & 4 & 4 \\
\hline
\end{tabular}

* Infection types follow 0 - 4 scale (Stakman et al., 1962): $0=$ No uredinia or other macroscopic sign of infection, No uredinia but hypersensitive necrotic or chlorotic flecks present, $1=$ Small uredinia surrounded by necrosis, $2=$ Small to medium uredinia surrounded by chlorosis or necrosis, $3=$ Medium-sized uredinia that may be associated with chlorosis, $4=$ Large uredinia without chlorosis and $\mathrm{X}=$ Random distribution of variable-sized uredinia on a single leaf. 
Table3. Infection types of 23 wheat cultivars against the most frequent leaf rust pathotypes at seedling stage under greenhouse condition during 2019/2020 growing season

\begin{tabular}{|c|c|c|c|c|}
\hline \multirow{2}{*}{ No. } & \multirow{2}{*}{ Genotype } & \multicolumn{3}{|c|}{ Leaf rust pathotypes / Infection type* } \\
\hline & & NTTJT & PTTTT & TTTBT \\
\hline 1 & Sids 1 & 3 & 3 & 3 \\
\hline 2 & Sids 12 & 4 & 4 & 3 \\
\hline 3 & Sids 13 & 1 & 1 & 4 \\
\hline 4 & Sids 14 & 3 & 3 & 3 \\
\hline 5 & Gemmeiza 7 & 4 & 4 & 4 \\
\hline 6 & Gemmeiza 9 & 0 & 0 & 0 \\
\hline 7 & Gemmeiza 11 & 3 & 4 & 4 \\
\hline 8 & Gemmeiza 12 & 3 & 3 & 4 \\
\hline 9 & Sakha 93 & 3 & 4 & 4 \\
\hline 10 & Sakha 94 & 4 & 3 & 3 \\
\hline 11 & Sakha 95 & 0 & 0 & 0 \\
\hline 12 & Misr 1 & 0 & 0 & 0 \\
\hline 13 & Misr 2 & 4 & 3 & 3 \\
\hline 14 & Misr 3 & 0 & 0 & 0 \\
\hline 15 & Giza 168 & 3 & 3 & 3 \\
\hline 16 & Giza 171 & 1 & 1 & 3 \\
\hline 17 & Shandweel 1 & 3 & 3 & 4 \\
\hline 18 & $\operatorname{Lr} 9$ & 3 & 3 & 4 \\
\hline 19 & $\operatorname{Lr} 10$ & 0 & 3 & 1 \\
\hline 20 & $\operatorname{Lr} 19$ & 2 & 1 & 3 \\
\hline 21 & $\operatorname{Lr} 24$ & 4 & 4 & 3 \\
\hline 22 & $\operatorname{Lr} 34$ & 4 & 3 & 4 \\
\hline 23 & Sr 2 comp. & 2 & 0 & 0 \\
\hline 24 & Morocco & 4 & 4 & 4 \\
\hline
\end{tabular}

* Infection types follow 0 - 4 scale (Stakman et al., 1962): $0=$ No uredinia or other macroscopic sign of infection, No uredinia but hypersensitive necrotic or chlorotic flecks present, $1=$ Small uredinia surrounded by necrosis, $2=$ Small to medium uredinia surrounded by chlorosis or necrosis, $3=$ Medium-sized uredinia that may be associated with chlorosis, $4=$ Large uredinia without chlorosis and $\mathrm{X}=$ Random distribution of variable-sized uredinia on a single leaf.

\section{Evaluation of wheat cultivars against crown rot under greenhouse condition:}

The observed results of the tested wheat cultivars against Fusarium crown rot pathogen showed that all the 29 tested wheat cultivars were susceptible to $F$. pseudograminurum causal organism. Disease incidence was ranged from 1.3 to 5 degrees based on disease incidence scale (Table 4). Moreover, there are significant differences were recorded among the tested cultivars in aspect to their tolerance potential against Fusarium pathogen under greenhouse conditions (Table
4). The highest disease incidence (5) with $F$. pseudograminiurum was observed with genotype $\operatorname{Lr} 19$ followed by genotype Gemmeiza 11 which recorded 4 based on the disease incidence scale (Table 4). On the other hand, the results showed that wheat cultivars Gemmeiza 9 and Misr 3 were the most tolerant cultivars among the all 29 tested cultivars while disease incidence recorded the lowest value (1.3). Similar results were observed with the repletion trial (Table 5). 
Table4. Disease incidence of 29 wheat cultivars against Fusarium crown rot at seedling stage under greenhouse condition during 2017/18 growing season

\begin{tabular}{|c|c|c|c|c|}
\hline No. & Genotype & Disease incidence & Grouping & Reaction \\
\hline 1 & Sids 1 & 2.7 & 3 & MS \\
\hline 2 & Sids 12 & 3.0 & 3 & MS \\
\hline 3 & Sids 13 & 2.3 & 2 & MR \\
\hline 4 & Sids 14 & 2.7 & 3 & MS \\
\hline 5 & Gemmeiza 7 & 3.0 & 3 & MS \\
\hline 6 & Gemmeiza 9 & 1.3 & 1 & $\mathrm{R}$ \\
\hline 7 & Gemmeiza 11 & 4.0 & 4 & S \\
\hline 8 & Gemmeiza 12 & 3.0 & 3 & MS \\
\hline 9 & Sakha 93 & 3.3 & 3 & MS \\
\hline 10 & Sakha 94 & 3.0 & 3 & MS \\
\hline 11 & Sakha 95 & 1.7 & 1 & $\mathrm{R}$ \\
\hline 12 & Misr 1 & 2.3 & 2 & MS \\
\hline 13 & Misr 2 & 3.0 & 3 & MS \\
\hline 14 & Misr 3 & 1.3 & 1 & $\mathrm{R}$ \\
\hline 15 & Giza 168 & 3.3 & 3 & MS \\
\hline 16 & Giza 171 & 3.0 & 3 & S \\
\hline 17 & Shandweel 1 & 3.0 & 3 & $S$ \\
\hline 18 & $\operatorname{Lr} 9$ & 3.0 & 3 & MS \\
\hline 19 & $\operatorname{Lr} 10$ & 3.0 & 3 & $S$ \\
\hline 20 & $\operatorname{Lr} 19$ & 5.0 & 5 & VS \\
\hline 21 & $\operatorname{Lr} 24$ & 3.0 & 3 & MS \\
\hline 22 & $\operatorname{Lr} 34$ & 3.7 & 3 & MS \\
\hline 23 & Sr 2 comp. & 2.0 & 3 & MR \\
\hline 24 & 249 (Check CR-MR) & 1.7 & 1 & MR \\
\hline 25 & Altay (Check CR-MR) & 2.0 & 2 & MR \\
\hline 26 & Carisma (Check CR-MR) & 1.7 & 1 & MR \\
\hline 27 & Kutluk (Check CR-S) & 3.0 & 3 & $\mathrm{~S}$ \\
\hline 28 & Seri (Check CR-S) & 3.0 & 3 & $\mathrm{~S}$ \\
\hline 29 & Sunco (Check CR-MR) & 2.3 & 2 & MR \\
\hline
\end{tabular}

Resistance (R); Moderate resistant (MR) and Susceptible (S) 
Table 5. Disease incidence of 29 wheat cultivars against Fusarium crown rot at seedling stage under greenhouse conditions during 2018/19 growing season

\begin{tabular}{|c|c|c|c|c|}
\hline No. & Genotype & Disease incidence & Grouping & Reaction \\
\hline 1 & Sids 1 & 2.7 & 3 & MS \\
\hline 2 & Sids 12 & 3.0 & 3 & MS \\
\hline 3 & Sids 13 & 2.3 & 2 & MR \\
\hline 4 & Sids 14 & 2.7 & 3 & MS \\
\hline 5 & Gemmeiza 7 & 3.0 & 3 & MS \\
\hline 6 & Gemmeiza 9 & 1.3 & 1 & $\mathrm{R}$ \\
\hline 7 & Gemmeiza 11 & 4.0 & 4 & $S$ \\
\hline 8 & Gemmeiza 12 & 3.0 & 3 & MS \\
\hline 9 & Sakha 93 & 3.3 & 3 & MS \\
\hline 10 & Sakha 94 & 3.0 & 3 & MS \\
\hline 11 & Sakha 95 & 1.7 & 1 & $\mathrm{R}$ \\
\hline 12 & Misr 1 & 2.3 & 2 & MS \\
\hline 13 & Misr 2 & 3.0 & 3 & MS \\
\hline 14 & Misr 3 & 1.3 & 1 & $\mathrm{R}$ \\
\hline 15 & Giza 168 & 3.3 & 3 & MS \\
\hline 16 & Giza 171 & 3.0 & 3 & $S$ \\
\hline 17 & Shandweel 1 & 3.0 & 3 & $S$ \\
\hline 18 & $\operatorname{Lr} 9$ & 3.0 & 3 & MS \\
\hline 19 & $\operatorname{Lr} 10$ & 3.0 & 3 & $\mathrm{~S}$ \\
\hline 20 & $\operatorname{Lr} 19$ & 5.0 & 5 & VS \\
\hline 21 & $\operatorname{Lr} 24$ & 3.0 & 3 & MS \\
\hline 22 & $\operatorname{Lr} 34$ & 3.7 & 3 & MS \\
\hline 23 & Sr 2 comp. & 2.0 & 3 & MR \\
\hline 24 & 249 (Check CR-MR) & 1.7 & 1 & MR \\
\hline 25 & Altay (Check CR-MR) & 2.0 & 2 & MR \\
\hline 26 & Carisma (Check CR-MR) & 1.7 & 1 & MR \\
\hline 27 & Kutluk (Check CR-S) & 3.0 & 3 & $\mathrm{~S}$ \\
\hline 28 & Seri (Check CR-S) & 3.0 & 3 & $S$ \\
\hline 29 & Sunco(Check CR-MR) & 2.3 & 2 & MR \\
\hline
\end{tabular}

\section{Correlation between crown rot and leaf rust incidence:}

The relation between the leaf rust and crown rot incidence was examined. The results showed a positive correlation between the 2 pathogens. Thus, the highest disease incidence values 4 of Puccinia fungus recorded on wheat cultivars Gemmeiza 11 which showed also the highest susceptibility potential toward Fusarium pathogen (fig. 1). Similar results were recorded on repetition trial during 2018-2019 growing seasons.

\section{Association between leaf rust and Crown rot:}

The association of leaf rust and Crown root was assessed through regression analysis. A positive relation between Crown root and leaf rust $\left(\mathrm{R}^{2}=0.34465\right)$ (Fig. 1 and 2). Similar findings were recorded with aspect to coloration between leaf rust and crown root where the coloration factor recorded $\left(\mathrm{y}=0.1965 \mathrm{x}+1.5151\right.$ with $\mathrm{R}^{2}$ $=0.4465$ and $\mathrm{y}=0.1667 \mathrm{x}+1.732$ with $\mathrm{R}^{2}=0.3763$ ) during season 2017/2018 and 2018/2019, respectively (Fig.3 and 4). 


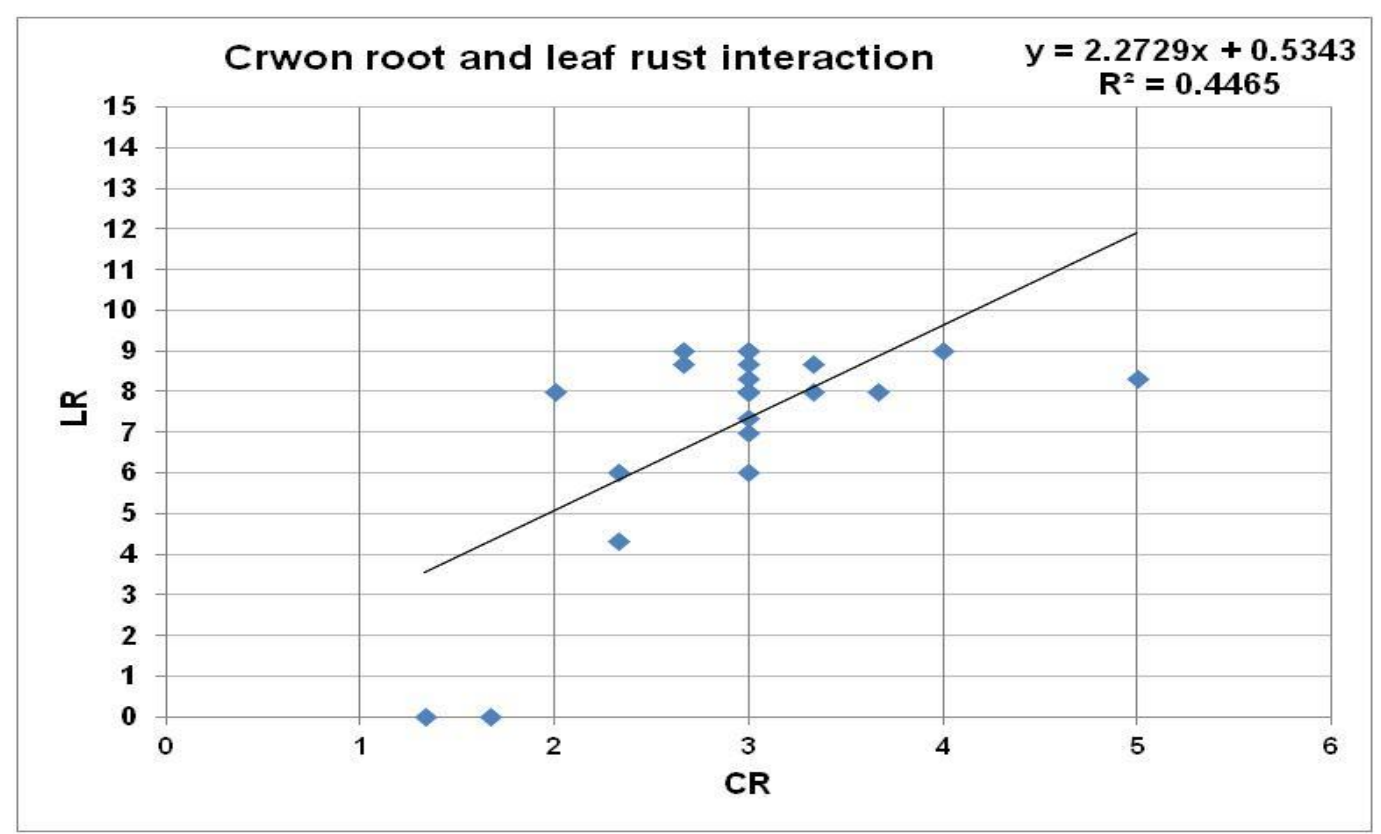

Fig. 1. Correlation between crown rot and leaf rust incidence during 2017-2018 growing season on 29 tested Egyptian wheat cultivars

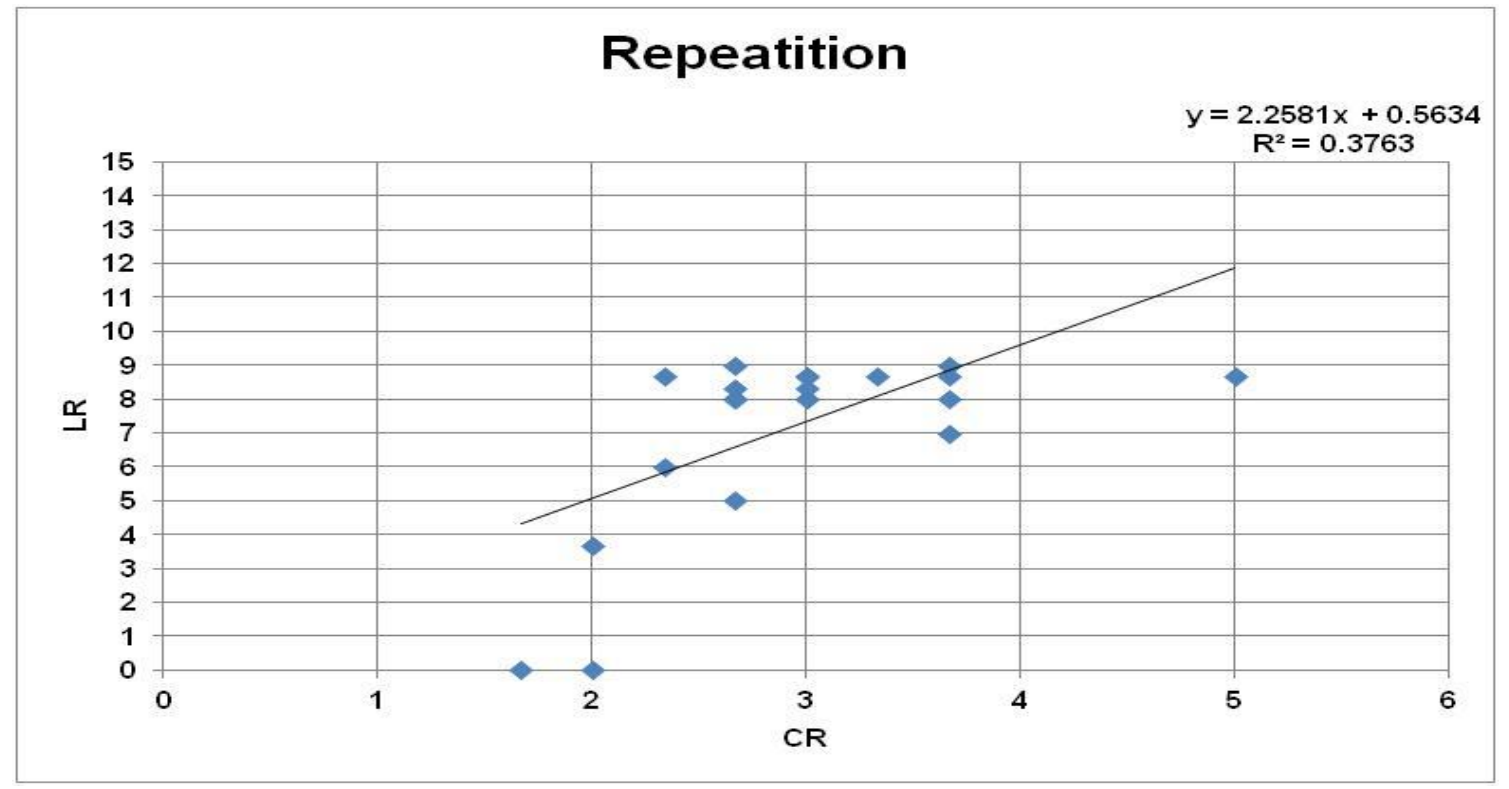

Fig. 2. Correlation between crown rot and leaf rust incidence during 2018-2019 growing season on 29 tested Egyptian wheat cultivars 


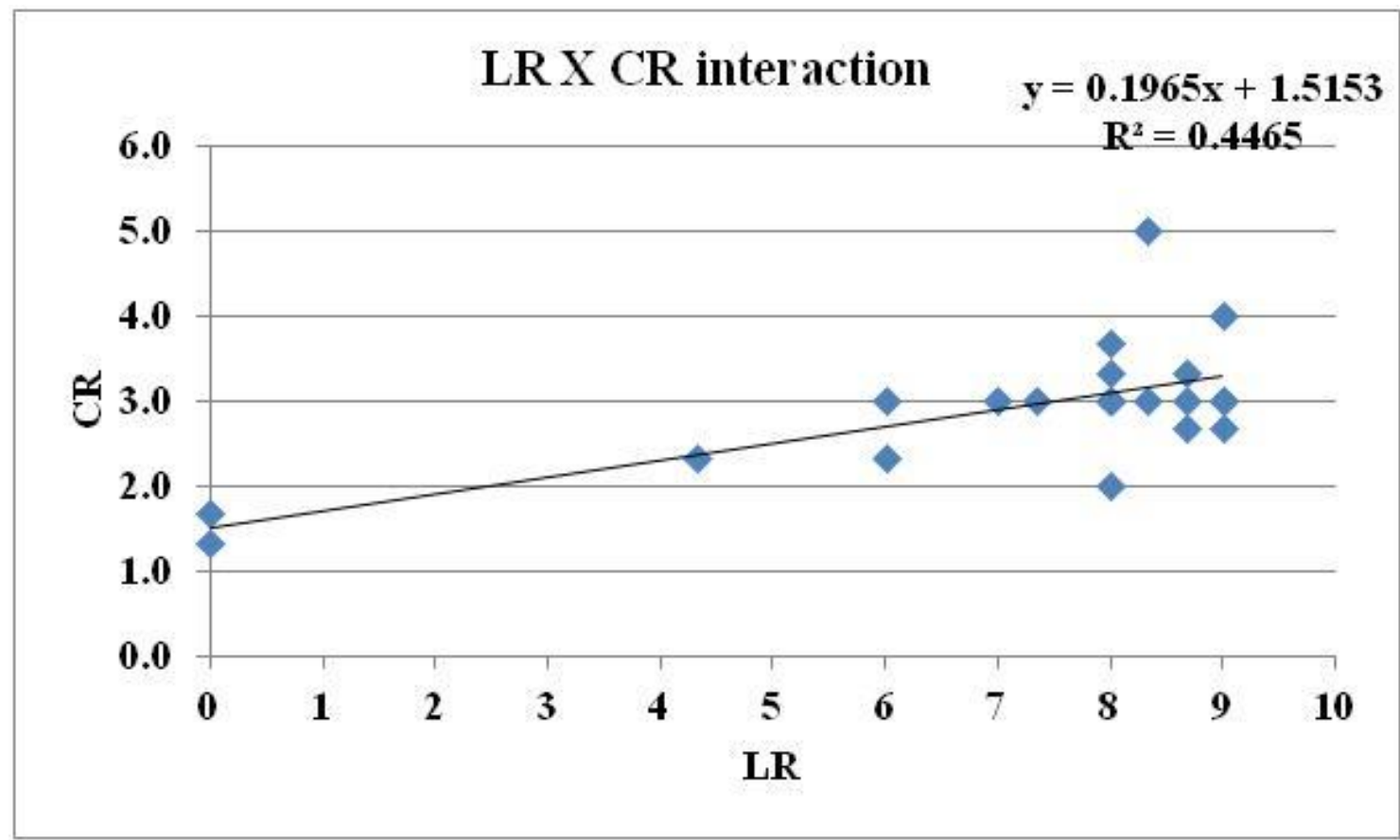

Fig. 3. Correlation between leaf rust and crown rot incidence during 2017-2018 growing season on 29 tested Egyptian wheat cultivars

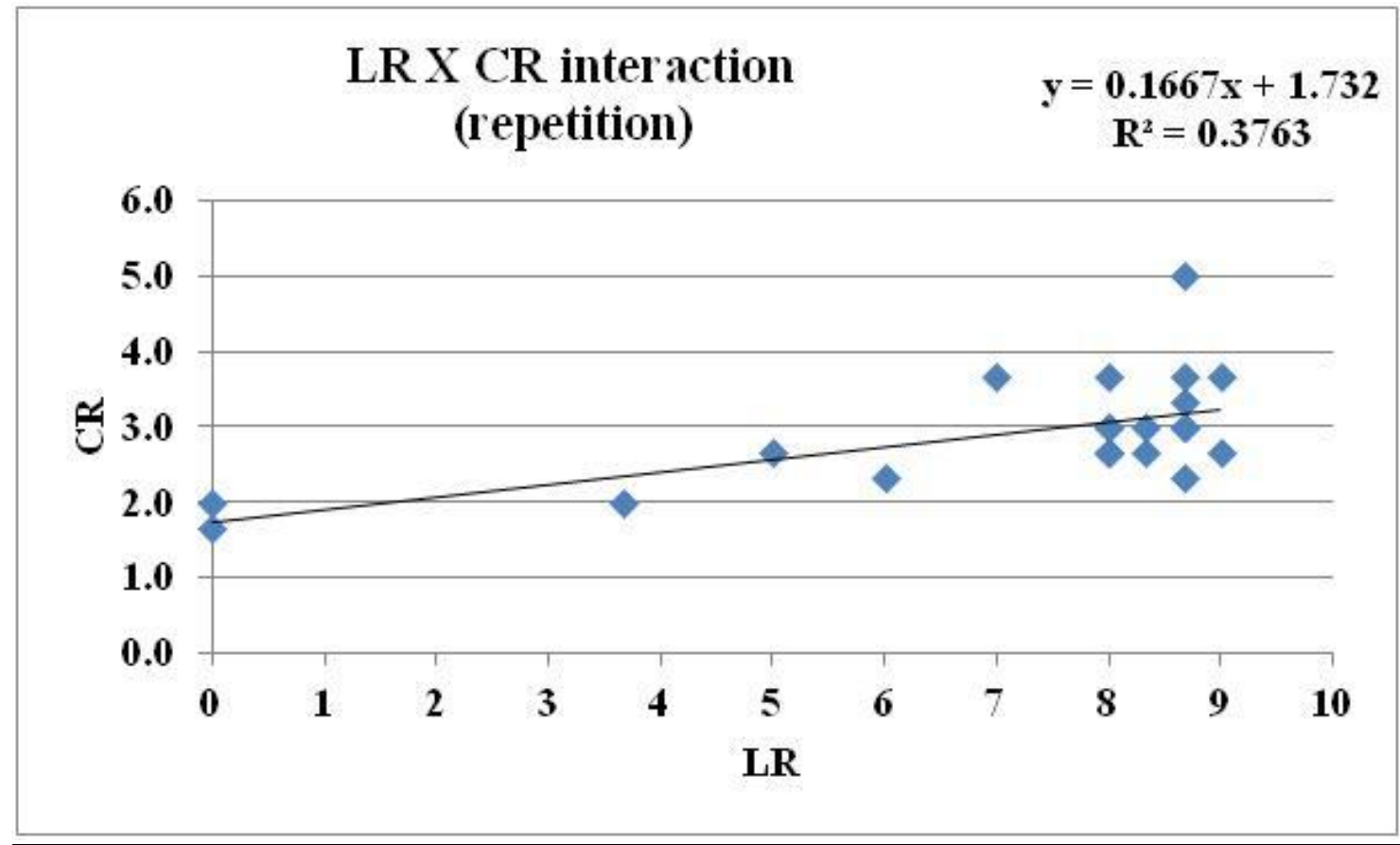

Fig. 4. Correlation between leaf rust and crown rot incidence during 2018-2019 growing season on 29 tested Egyptian wheat cultivars 
Sodium dodecyl sulfate-polyacrylamide gel electrophoresis of wheat cultivars.

The results of SDS-PAGE presented in Table 6 and Fig. 5 showed that 11 protein bands with molecular weights ranging from 79 to $8.5 \mathrm{kDa}$ are contained in wheat plants. Nine protein bands were appeared in Misr 2 and Sids 14 while 10 protein bands were appeared in Giza171, Sakha 95 and Gemmeiza11. However, 11 protein bands were appeared in Gemmeiza12, Morocco,
Misr1, Shandweel1, Sakha94 and Giza168. Band with molecular weight $44 \mathrm{kDa}$ was disappeared in Giza171 whereas, Band with molecular weight $45 \mathrm{kDa}$ only appeared in Giza171. Band with molecular weight 79 kDa was disappeared in Giza171, Misr2 and Sids14.

The Band with molecular weight $15 \mathrm{kDa}$ was disappeared in Misr2, Sids14, Sakha95 and Gemmeiza11. This band from the obtained data was correlated to resistance to puccinia rust.

Table 6. Sodium dodecyl sulfate-polyacrylamide gel electrophoresis of wheat cultivars

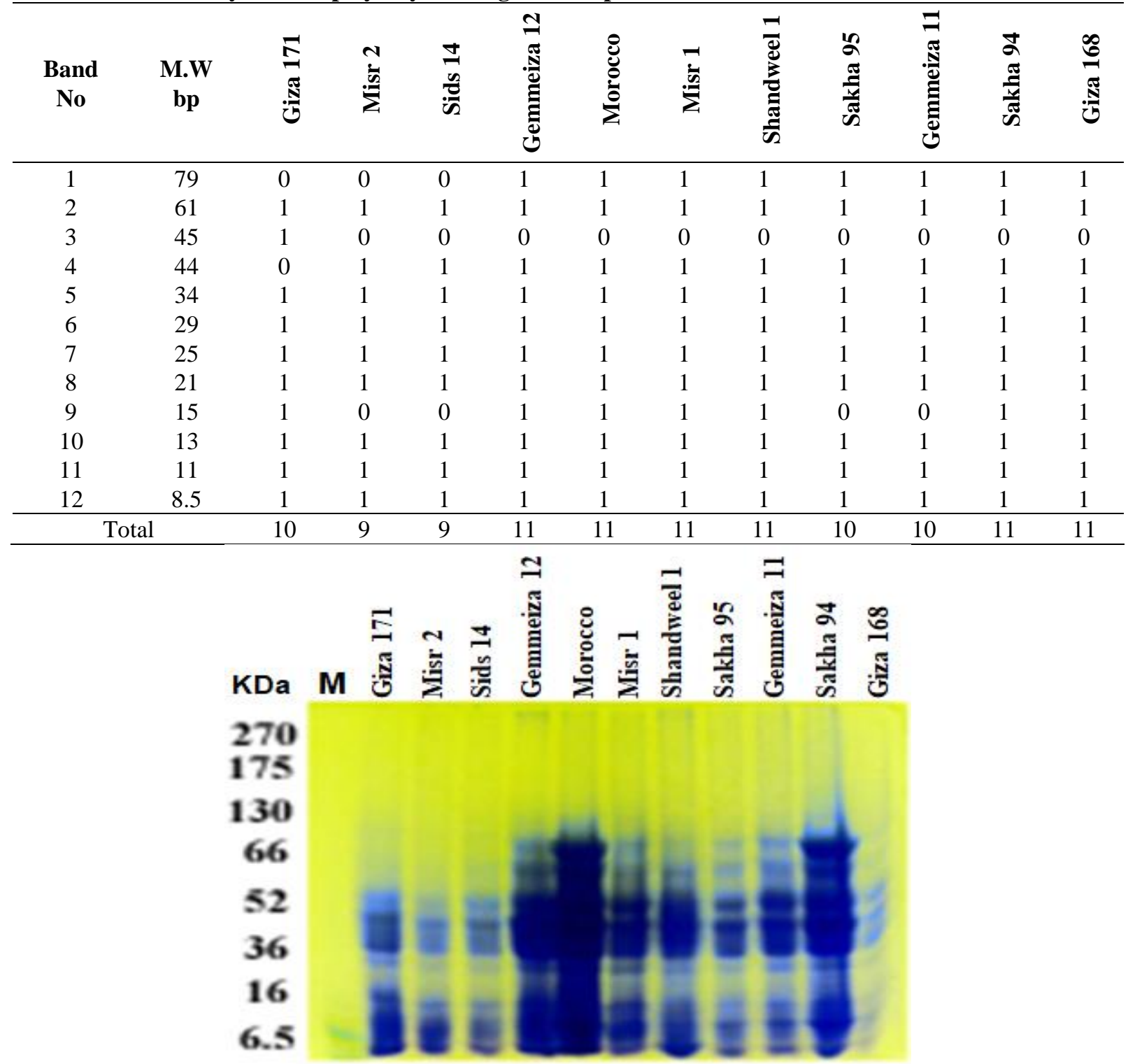

Fig. 5. Sodium dodecyl sulfate-polyacrylamide gel electrophoresis of wheat cultivars 


\section{Discussion}

A major priority of plant pathology and plant breeding is to release high-yielding disease resistant wheat cultivar to specific abiotic and biotic stresses (Zhao et al., 2020; Zhao et al., 2021). FCR is a major biotic factor reducing the yield of wheat especially in drought persistent locations of the world. Despite the broad awareness of losses caused by $F$. pseudograminearum, till now no durable resistant cultivars have been released. The absence of sufficient knowledge, technical know-how and limited understanding of the genetic basis have been the key challenges in developing resistant cultivars (Pariyar et al., 2020). FCR characterized by stem base or leaf sheath browning and whiteheads, is a frequent and severe disease in many parts of the semiarid regions worldwide (Chakraborty et al., 2006). Growing resistant and tolerant cultivars has long been recognized as a key component in effectively managing FCR damage (Purss, 1966). Effective breeding of resistant cultivars requires effective and repeatable screening method (s) as well as good and diverse sources of resistance, which do not only provide detectable effects in different environments but should also show no significant negative interaction with other traits of agronomic importance. Understanding the genetics of resistance sources can further enhance breeding efficiency.

Moreover, $P$. triticina, the pathogen causing leaf rust, is present in most of the wheat-growing areas. Genetic resistance remains the most effective, economical, and environmentally friendly strategy for controlling the negative impact of this disease.

In this study, greenhouse tests of seedling resistance to leaf-rust of the five wheat cultivars i.e. Gemmeiza 9, Sakha 95, Misr 1, Misr 3 and Sr 2 comp. showed high resistance to the three leaf rust races i.e. NTTJT, PTTTT and TTTBT. On the other hand, the four wheat cultivars i.e. Sids 13, Giza 171, $L r 10$ and $L r 19$ showed resistance to the two leaf rust races i.e. NTTJT and PTTTT and susceptible to race TTTBT. While the other 14 wheat cultivars were susceptible to the three races. Similar results were reported by Sallam et al., 2016 and Mabrouk et al., 2019.

In the present study, the relation between 2 important invading pathogens of wheat i.e. $F$. pseudograminiarum and Puccinia was investigated in order to know if there is a possible correlation between those two important pathogens or not. These informations are quite important in predication analysis of the infection incidence on wheat plants when attacked by one of these pathogens.

The obtained results from the screening test of the tested wheat cultivars are very reliable for detecting the strong resistance cultivars. The eight wheat cultivars i.e. Gemmeiza 9, Sakha 95, Misr 3, Sr 2 comp., 249 (Check CR-MR), Altay (Check CR-MR), Carisma (Check CRMR) and Sunco (Check CR-MR) were resistant to crown rot. However, the other tested wheat cultivars were susceptible. Similar results were found by Wallwork et al. (2004).

The wheat cultivars: Gemmeiza 9, Sakha 95, Misr 3, $\mathrm{Sr} 2$ comp. with resistance to both FCR and leaf rust is the most important to reduce yield losses of both diseases. Thus, these wheat cultivars would be excellent sources for CR and leaf rust resistance, efficient and successful use of these cultivars in the practices of breeding program.

Band with molecular weight $15 \mathrm{kDa}$ was disappeared in Misr2, Sids14, Sakha 95 and Gemmeiza11. Theses cultivars most susceptible to rust disease. It clear that band with molecular weight of 15 $\mathrm{kDa}$ was correlated to resistance to puccinia rust. This was agreed with Rabia et al., (2014) they reported that, the level of protection afforded was significantly correlated with the ability to increase PR protein expression. Also, Ahmed (2016) confirmed that new protein bands with low molecular weight had a progressive relationship on reducing disease severity of plant diseases. The most effective and practical method to protect wheat from FCR using host resistance is the most effective and sustainable strategy to control this disease. However, conventional breeding programs have been limited due to a lack of effective resistance genes (Rudd et al., 2001).

\section{CONCLUSIONS}

The results indicate that positive correlation between F. pseudograminearum and Puccinia fungi was detected on wheat cultivars.

\section{ACKNOWLEDGEMENT}

we thank Dr. Walid M. El-Orabey for providing leaf rust races used in this study supplying the seeds of monogenic lines and Egyptian wheat varieties and also I would like to thank him for his suggestions on preparing the manuscript.

\section{REFERENCES}

Ahmed, G. A. 2016. Evaluation of the efficacy of some phenolic compounds in controlling bacterial spot disease and biochemical changes associated on pepper plants under greenhouse conditions. J. Plant Prot. and Path., Mansoura Univ. 7(10): 655-662. 2016. 
Chakraborty, S., C. J. Liu, V. Mitter, J. B. Scott, O. A. Akinsanmi, S. Ali, R. Dill-Macky, J. Nicol, D. Backhouse and S. Simpfendorfer. 2006. Pathogen population structure and epidemiology are a key to wheat crown rot and Fusarium head blight management. Australas. Plant Pathol. 35: 643-655.

Dubin, J., L. Gilchrist, J. Reeves and A. McNab. 1997. Fusarium head scab: global status and future prospects. Proceedings of a Workshop, El Batan (Mexico). 10- 1396- 10-17-96. Mexico (DF (Mexico)): CIMMYT. Vi.130 p.

El-Orabey, W.M., N.I.Abd El-Malik, M.A. Ashmawy and M.A. Abou-Zeid. 2017. Reduction in grain yield caused by leaf rust infection in seven Egyptian wheat cultivars. Minufiya J. Plant Protection. 2: 71-81.

El-Orabey, W.M., A.Hamweih, M.A. Gad and S.M. Ahmed. 2019. Virulence and molecular polymorphism of Puccinia triticina pathotypes in Egypt. Int. J. Phytopathol. 08(03):111-122. Doi: 10.33687/phytopath.008.03.3087.

El-Orabey, W.M., R.I. Omara and M.A. Abou-Zeid. 2018. Diversity and virulence dynamics within Puccinia triticina populations in Egypt. J. Plant Prot. and Path., Mansoura Univ. 9 (11):735-745.

Elyasi-Gomari, S. and G.M. Lesovaya. 2009. Harmfulness of wheat leaf rust in Eastern part of forest-steppe of Ukraine. Arch. Phytopathol. Plant Protect. 42(07):659-665.

Ferrigo, D., A. Raiola and R. Causin. 2016. Fusarium toxins in cereals: occurrence, legislation, factors promoting the appearance and their management. Molecules. 21:627.

German, S.E., A. Barcellos, M. Chaves, M. Kohli, P. Campos and L. Viedma. 2007. The situation of common wheat rusts in the Southern Cone of America and perspectives for control, Aust. J. Agric. Res. 58: 620-630.

Goswami, R.S. and H.C. Kistler. 2004. Heading for disaster: fusarium graminearumn on cereal crops. Mol Plant Pathol. 5:515-525.

Laemmli, U.K. 1970. Cleavage of structural proteins during the assembly of the head of bacteriophage T4. Nature. 227: 680-685.

Mabrouk, O.I., W.M. El-Orabey and S.M. Esmail. 2019. Evaluation of wheat cultivars for slow rusting resistance to leaf and stem rust diseases in Egypt. Egypt. J. Phytopathol. 47(2): 1-19.

McMullen, M., G. Bergstrom, E. De Wolf, R. Dill-Macky, D. Hershman, G. Shaner and D. Van Sanford. 2012. A unified effort to fight an enemy of wheat and barley: fusarium head blight. Plant Dis. 96:1712-1728.

McMullen, M., R.Jones and D.Gellenberg. 1997. Scab of wheat and barley: A re-emerging disease of devastating impact. Plant Dis. 81:1340-1348.

Mudge, A.M., R.D.Macky, Y.Dong, D.M.Gardiner, R.G.White and J.M. Manners. 2006. A role for the mycotoxin deoxynivalenol in stem colonisation during crown rot disease of wheat caused by Fusarium graminearum and Fusarium pseudograminearum.
Physiological and Molecular Plant Pathology. 69:1-3. July-September. 73-85. 08855765. doi:10.1016/j.pmpp.2007.01.003.

Nganje, W.E., S. Kaitibie, W.W. Wilson, F.L. Leistritz and D.A. Bangsund. 2004. Economic impacts of Fusarium head blight in wheat and barley:1993-2001. Agribus Appl Econ Rep. 538.

Pariyar, S.R., G.E.Gul erginbas-Orakci, S.Dadshani, O.B.Chijioke, J. Léon, A.A. Dababat and F.M. Grundler. 2020. Dissecting the genetic complexity of fusarium crown rot resistance in Wheat. Scientific Reports. 10: 113. (https://doi.org/10.1038/s41598-020-60190-4).

Plake, B.S. and B.E. Kemmerer. 1987. Statgraphics: Neil W. Polhemus and the Statistical Graphics Corporation. Rockville, MD: STSC. Computers in Human Behavior. 3: 289-298.

Pruss, S.S. 1966. Studies of varietal resistance to crown rot of wheat caused by Fusarium graminearum Schw. Qld. J. Aric. Anim. Sci. 23: 475-498.

Rabia, N., B.Asghari, L.Neil, D.G. Wilson and H.R. Thomas. 2014. Pathogenesis-related protein expression in the apoplast of wheat leaves protected against leaf rust following application of plant extracts. Phytopathology.104(9): 933-944.

Rudd, J. C., R. D.Horsley, A. L. McKendry and E. M. Elias. 2001. Host plant resistance genes for Fusarium head blight: sources mechanisms and utility in conventional breeding systems. Crop Sci. 41:620-627.

Sallam, M.E., W.M. El-Orabey and R.I. Omara. 2016. Seedling and adult plant resistance to leaf rust in some Egyptian wheat genotypes. African J. of Agricultural Research. 11(4): 247-258.

Shahin, S.I. and W.M. El-Orabey. 2016. Assessment of grain yield losses caused by Puccinia triticina in some Egyptian wheat genotypes. Minufiya J. Agric. Res. 41(1): 29-37.

Stakman, E.C., D.M. Stewart, W.Q.Loegering. 1962. Identification of physiologic races of Puccinia graminis var. tritici. U.S, Agric. Res. Serv.ARS E. 617:1-53.

Wallwork, H., M.Butt, J. P. E. Cheong and K. J. Williams. 2004. Resistance to crown rot in wheat identified through an improved method for screening adult plants. Australasian Plant Pathology. 33: 1-7.

Wamishe, Y.A. and E.A. Milus. 2004. Seedling resistance genes to leaf rust in soft red winter wheat. Plant Dis. 88:136-146.

Zhao, L., N.R.Abdelsalam and Y. Xu. 2020.Identification of two novel Hessian fly resistance genes H35 and H36 in a hard winter wheat line SD06165. Theor Appl Genet. https://doi.org/10.1007/s00122-020-03602-3.

Zhao, L., S.Liu, N. R.Abdelsalam, B. F.Carver and G.Bai. 2021. Characterization of wheat curl mite resistance gene Cmc4 in OK05312. Theoretical and Applied Genetics. 134(4):993-1005. 


\section{الملخص العربي \\ العلاقة بين مقاومة صدأ الأورلق ومرض عفن التاج الفيوزاريومي في بعض أصناف القمح المصري محمد علوي سليم ، عبير حمدي مخلوف و جمال عاشور أحمد}

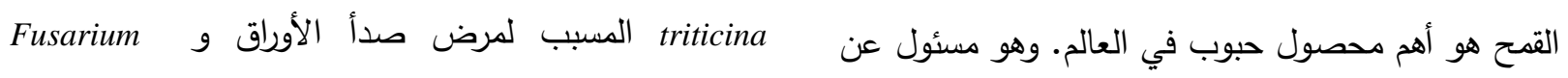

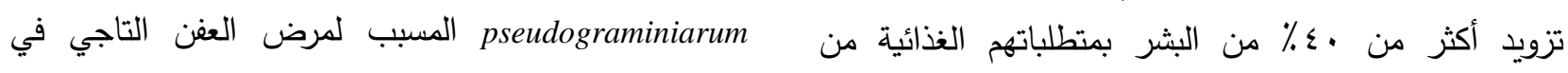

الكربوهيدرات والعناصر الغذائية الأساسية الأخرى. لسوء القهح. في هذه الدراسة، تم تقدير المقاومة لـ وب تركيباً وراثيًا

الحظ ، يتعرض القـح للهجوم من قبل العديد من مسببات مختلفًا من القهح المصري ضد ثلاثة سلالات من صدأ

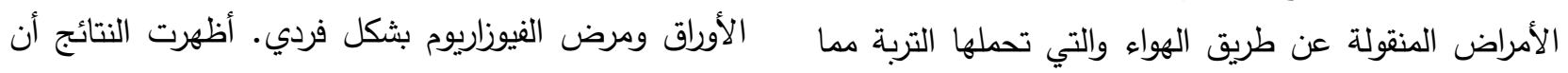

Puccinia أدى إلى خسائر فادحة من حيث الكمية والنوعية. في مصر احتمال تحمل التراكيب الوراثية المختبرة تجاه ، لا يعد القهح مجرد محصول حبوب غذائي ولكنه يعتبر أو Fusarium pseudograminiarum كانت متباينة مفتاح الأمن الغذائي وهناك فجوة كبيرة بين إنتاج حبوب بثكل كبير • تم تقييم العلاقة بين الإصابة بالمرضين وأشارت القهح ومعدلات الاستهلاك المحلى. لذلك ، فإن إنقاذ كل حبة النائج النتائج إلى وجود علاقة ارتباط موجبة بين الإصابة بصدأ

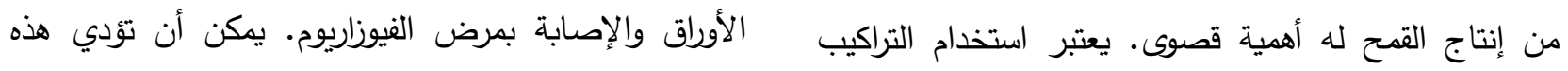
النتائج إلى تصميم نماذج خاصة يمكن استخدامها في التتبؤ الوراثية المقاومة لمسببات الأمراض أحد أكثر التقنيات فعالية وذات الصلة التي يمكن استخدامها في المعركة بين علماء بحدوث أحد الممرضين عندما يهاجم الآخر نباتات القهح. أمراض النبات ومسببات الأمراض الخطرة مثل Puccinia 